\title{
The Study on Compulsive Buying as Self-Defeating Behavior : Focused on Social Exclusion Factor
}

\author{
Woong-Hee HAN \\ Associate Professor, Dept. of Business Administration, Myongji University, Seoul, Korea \\ E-mail:whhan@mju.ac.kr
}

Received: 12 March 2020. Revised: 21 April 2020. Accepted: 25 April 2020

\begin{abstract}
Purpose - This study investigated the effect of the social exclusion experience on the compulsive buying tendency. The purpose of current study is to examine the mechanism through compulsive buying, one of selfdefeating behaviors. While previous studies on compulsive buying focused only on the mechanism of psychological escapism to overcome negative emotions, this study intends to expand the study on the causes of compulsive buying by presenting a social exclusion experience as one of the causes of negative emotions.

Research design and methodology - Present study was performed with 114 university students. Participants were assigned to one of two groups at random - the social exclusion experience group and the social exclusion nonexperience group. Authors analyzed the influence of social exclusion experience on the compulsive buying.

Results - The social exclusion experience group showed compulsive buying tendency than the social exclusion non-experience group.

Conclusions - People with social exclusion experiences avoid self-awareness and show cognitive narrowing, which leads to compulsive buying. Academic implications and practical implications of current research were discussed and the limitations were suggested.
\end{abstract}

Keywords: Compulsive Buying, Social Exclusion, Self-Defeating Behaviour

JEL Classification Code: D11, D12, M31.

(c) Copyright: The Author(s)

This is an Open Access article distributed under the terms of the Creative Commons Attribution Non-Commercial License (http://Creativecommons.org/licenses/by-nc/4.0/) which permits unrestricted noncommercial use, distribution, and reproduction in any medium, provided the original work is properly cited. 


\section{Introduction}

Compulsive buying is a purchase behavior that is obsessed with buying. Compulsive buyers display repetitive and overwhelming urges to buy goods that are sometimes useless (Kukar-Kinney, Rigway, and Monroe, 2009). Compulsive buying is an increasing phenomenon which is characterized by excessive consumption. Advertising, online retail websites, and easy credit facilities can induce the buying of items that are not objectively needed (Roberts, 1998). Compulsive buying regularly results in a number of difficulties, including substantial debts, legal problems, personal distress, and marital conflict (McElroy, Keck, and Phillips, 1995). According to Christenson, Faber, DeZwaan, Raymond, Specker, and Ekern (1994), 58\% of compulsive buying entail going into debt. $42 \%$ of compulsive buyers cannot make payment of items bought on compulsively. A small minority (8\%) face criminal or legal complications and are exposed to feelings of guilt. Compulsive buyers spend more than they can afford and therefore take out loans or extended credit, and find themselves in debt (Weinstein, Mezig, Mizrachi, \& Lejoyeux, 2015).

Previous research investigated antecedents of compulsive buying behavior. For example, Achtziger, Hubert, Kenning, Raab, and Reisch (2015) proved that lower levels of self-control are related to higher levels of compulsive buying. Kukar-Kinney, Scheinbaum, and Schaefers (2016) showed that hedonic motivation is associated with compulsive buying. It is required to explain the phenomenon by paying attention to the psychological and emotional aspects of the compulsive buying agent. Compulsive buyers may employ obsessive buying behaviors to cope with and alleviate their undesirable, negative mood states (Faber \& Christenson, 1996). Negative affect triggers compulsive buying. Coping theory suggests that individuals continuously adjust cognitive and behavioral efforts in order to manage internal/external demands that are perceived as exceeding their personal resources (Lazarus and Folkman, 1984). Based on the coping theory, Faber (2004) theorized that compulsive buying function as an escape tactics from negative affect states. Specifically, escape theory posits that self-awareness of a problem may be so painful that consumers partake in immediate, specific and self-destructive tasks like compulsive buying or binge eating as a means of escape (Yi, 2012).

Our research puts forward social exclusion experience as the driver of compulsive buying. Individuals who have experienced social exclusion use a strategy called cognitive narrowing to escape negative emotions, which can affect their cognitive structure and methods and generate various forms of deviant behavior. In other words, the selfdefeating behavior that often appears to those who have experienced social exclusion is the result of cognitive narrowing to cope with negative emotions, and present study will examine the mechanism through compulsive buying, one of self-defeating behaviors. The principle of psychological escapism to overcome negative emotions is used to explain various self-defeating behaviors such as binge eating and suicide (Heatherton and Baumeister, 1991), impulsive buying (Han, 2020b, 2020c) and cognitive impairments such as black and white logic and overgeneralization (Johnson, Connors and Tobin, 1987), pseudodiagnosticity biases (Han, 2020a). While previous studies on compulsive buying focused only on the mechanism of psychological escapism to overcome negative emotions, this study intends to expand the study on the causes of compulsive buying by presenting a social exclusion experience as one of the causes of negative emotions. Based on the results of current research, the theoretical implications for social exclusion, self-defeating behavior, negative emotions, and compulsive buying are likely to be found, and practical implications from both marketing and consumer protection are expected to be derived.

\section{Literature Review}

\subsection{Compulsive Buying}

Purchase of goods is a normal activity in our life. For some consumers and in specific situations, purchases might be unplanned and initiated on the spot with a strong urge for pleasure. Specifically, some consumers show repetitive, and irresistible urges to purchase useless goods. This kind of obsessed purchase behavior is generally known as compulsive buying and can lead to psychological and economic distress (Billieux, Rochat, My LienRebetz, and Van der Linden, 2008). Faber and O'Guinn (1989) suggested that compulsive buying is chronic and repetitive purchasing behavior that becomes a primary response to negative events and feelings (Weinstein, Maraz, Griffiths, Lejoyeux, and Demetrovics, 2016).

Compulsive buying can be defined as chronic and repetitive buying behavior, a persistent and unconscious way to deal with negative emotions (Faber and O'Guinn, 1992; O'Guinn and Faber, 1989). Compulsive buying can be satisfying in the short run, but ultimately hurts individuals and others. Compulsive buying is not just about 
interpersonal conflict and financial difficulties, but it can also lead to serious negative consequences, such as divorce, embezzlement, theft, and even suicide.

Compulsive consumption is commonly viewed to be an element of the dark side of consumer behavior (Hirschman, 1991). Compulsive consumption is defined as "a response to an uncontrollable drive or desire to obtain, use, or experience a feeling, substance, or activity that leads an individual to repetitively engage in a behavior that will ultimately cause harm to the individual and/or to others" (O'Guinn and Faber, 1989). Research suggests that compulsiveness is manifested in binge eating (Faber, Christenson, De Zwaan, \& Mitchell, 1995), hyperactive online and in-store purchasing (Johnson and Attmann, 2009), gambling (Balabanis, 2002), hoarding (Cherrier and Ponnor, 2010), credit card misuse (Palan, Morrow, Trapp, and Blackburn, 2011).

Ridgway, Kukar-Kinney, and Monroe (2008) defined compulsive buying as a preoccupation on repetitive and uncontrolled buying. Compulsive consumers are vulnerable because they cannot control over shopping (KukarKinney et al., 2016). As a result, compulsive consumers may end up with high level of debt as well as social and family problems (Achtziger et al., 2015; O'Guinn and Faber, 1989). Compulsive buying leads to undesirable consequences (e.g., personal debt and damage of family relationships) (Gallagher, Watt, Weaver, and Murphy, 2017).

The specialized term for compulsive buying issue is oniomania, gotten from the Greek words onios signifying "available to be purchased" and lunacy signifying "madness." The root expressions of the term may infer that compulsive purchasers' crazed dependence might be activated and directed by deals advancements. The research proposes that compulsive buyers have more prominent information on store costs, increase more prominent exchange an incentive from cost advancements, have more significant expense cognizance and deal inclination, have more noteworthy on-line shopping propensities and display higher charge card maltreatment than non-enthusiastic purchasers (Kukar-Kinney, Ridgway, and Monroe, 2012; Palan et al., 2011).

Neurological research reveals that the brain activity in decision-making regions differs significantly between compulsive and non-compulsive buyers (Raab, Elger, Neuner, and Weber, 2011), which could possibly provide an explanation for why compulsive buyers lose control and fall into addiction. In the United States, the prevalence of compulsive buying behavior among consumers is estimated to be $5.8 \%$, the vast majority of whom, roughly $80 \%$, are female (Koran, Faber, Aboujaoude, Large, and Serpe, 2006).

The late 1980s and mid-1990s saw an inundation of papers on compulsive buying behavior when all is said in done and compulsive consumption specifically. Consumer study started by perceiving and characterizing the phenomenon. Faber and O'Guinn (1988) declared that it would be a positive early advance to build up a demonstrative test so as to distinguish compulsive shoppers. Valence, d'Astous, and Fortier (1988) before long built up a compulsive buying scale surrounded on purchaser tension. Faber and O'Guinn (1992) reacted with a seven-item measure that better catches extraordinary instances of compulsive purchasing conduct. Throughout the following two decades, researchers directed various experimental examinations utilizing these two compulsive purchasing scales, remembering a few for mental patients with urgent propensities (Johnson and Attmann, 2009; Cherrier and Ponnor, 2010; Palan et al., 2011; Roberts, 1998). In the marketing area, the less highlighted aspect of consumer behavior has become a matter of developing significance with various investigations looking at compulsive consumption and its results.

Most compulsive buyers exhibit preoccupation in their repetitive shopping, as in obsessive behavior (Faber and O'guinn, 1992). Compulsive buying is shown to have a positive correlation with three facets of impulsivity: urgency, lack of perseverance and lack of premeditation (Billieux et al., 2008). Dittmar (2005) argue that three factors (i.e., self-discrepancies, materialistic values, and ideal-self purchase motivation) drive compulsive buying. Gallagher et al. (2017) suggest that impaired functioning in individual causes compulsive buying which can reduce negative emotion. Duroy, Gorse and Lejoyeux (2014) report that loss of control, temptations from marketing (i.e. sale events) and positive emotion motivate people to buy compulsively.

Compulsive buyers are fixated on purchasing, and they show tedious, overwhelming, and overpowering inclinations to buy products that are much of the time pointless and additionally unused things. Compulsive buyers regularly purchase garments from popular designers and "best in class" (i.e., costly) things so as to dazzle others, and they shop more than control groups (Kukar-Kinney et al., 2009). The Internet retail condition empowers them to be separated from everyone else while achieving their compulsion and it allows a low-to-nonexistent degree of social association. Buy in both on the web and disconnected stores is a desolate (solo) action and compulsive buyers favor purchasing on the web to disconnected. In these cases, hedonic motives impact shopping and are identified with the positive sentiments they experience while purchasing (e.g., joy, energy). Compulsive buyers firmly center more around the purchasing procedure itself and the securing of the item(s) than on their ownership or use. 
Furthermore, compulsive buyers often describe an increasing level of urge or anxiety that can only lead to a sense of completion when a purchase is made (Black, 2007).

Compulsive buyers spend four times more time on the Internet than noncompulsive buyers, but only when this technology gives them the opportunity to buy (Lejoyeux, Mathieu, Embouazza, Huet, and Lequen, 2007). Compulsive buying can be enhanced by the online retail environment because it is free from social interaction (Dittmar, Long, and Bond, 2007). The number of women shopping online is increasing, although relatively little is known about gender differences when buying online (Dittmar et al., 2007). There are three main features of compulsive buying experience of an uncontrollable desire to buy, lack of control over purchase, and continuous purchase without consideration of the negative result on their lives (Dittmar et al., 2007).

The main motivation for compulsive buying is not a desire for a product, but a temporary improvement in mood or self-esteem (Faber, 2000; O'Guinn and Faber, 1989). Many compulsive buyers do not use their products at all, and after months or years, these items remain unpacked or untagged (O'Guinn and Faber, 1989). Changes in arousal levels are also key motivations for compulsive buying. Compulsive buyers use the expressions 'high', 'exciting', 'strong', 'enhanced' and 'out of control', explaining that their buying experience was very exciting (Faber and Christenson, 1996). It may be thought that these behaviors can change the emotional state, but in practice these behaviors do not eliminate the unpleasant feelings and, as a result, can make the emotions worse (Baumeister, Vohs, DeWall, and Zhang, 2007). Consumers try to overcome negative emotions through purchasing behavior, which can make them feel better at the moment, but when they feel like they have wasted money or fail to keep their resolve not to buy it, they immediately feel guilty right after the purchase action, which can lead to depression or a loss of self-esteem. As a result, they try to overcome negative self-assessment, which leads to a vicious cycle that is increasingly difficult to stop as it induces purchasing behavior again (Rawn and Vohs, 2010).

Although factors promoting positive mood state (e.g., nice scents, attractive colors, or pleasant music) may elicit impulse purchase behaviors, compulsive buying more frequently occurs in contexts of negative affect (Billieux et al., 2008). Positive mood including relief is the consequences of compulsive buying. However, this relief is temporal and followed by more anxiety. Purchase acts as a self-regulatory mechanism aiming at reducing one's depressive feelings and purchase make consumers feel better about themselves (Christenson et al., 1994; Kukkar-Kinney et al., 2009). Wearing new chic garments may help a few buyers with feeling better about themselves (Kukkar-Kinney et al., 2009).

Compulsive buying shows two types of conduct: impulsive buying and obsessive-compulsive buying (Ridgway et al., 2008). Impulsive buying alludes to an impromptu buy that is joined by quick dynamic and emotional predisposition for sure-fire ownership, where shoppers purchase precipitously, unreflectively, promptly, and dynamically (Kacen and Lee, 2002). Then, obsessive-compulsive buying alludes to an uncontrolled urge that is joined by distraction in purchasing and dull purchasing so as to lessen tension (Ridgway et al., 2008). Compulsive buyers often experience pain in their perceptions of themselves and are accustomed to patterns that rely on purchases to cure these negative emotions. Abominable self-awareness can lead to depression or anxiety, and it is not surprising that compulsive buyers show high depression and anxiety (Schlosser, Black, Repertinger, and Freet, 1994). This negative self-assessment ultimately circumvents self-awareness, and one way to avoid self-awareness is to focus on the specific, immediate, and low-level tasks including shopping and purchasing. This phenomenon is called cognitive narrowing and can be seen as a form of misregulation (Rawn and Vohs, 2010). This cognitive narrowing can lead to uncritical and irrational thinking that leads people to fall into unrealistic daydreaming or to fail to accurately judge the validity of certain beliefs (Heatherton and Baumeister, 1991). A feature common to compulsive buyers is "fantasy," which they say becomes more powerful during purchases and imagines being praised by others (Krueger, 2000). As indicated by Miltenberger, Redlin, Crosby, Stickney, Mitchell, Wonderlich, and Smyth (2003), when compulsive purchasers are approached to portray how they felt before compulsive buying, $53 \%$ state they are dismal or discouraged and $21 \%$ tense or on edge. When gotten some information about their emotions after a compulsive buying, $42 \%$ felt remorseful and $21 \%$ felt tragic or discouraged. Compulsive buying gets impermanent help from their negative feelings when they buy things.

\subsection{Self-Defeating Behavior}

Despite of need for a sense of belonging, sometimes we are excluded from others. Social exclusion is generally experienced as a threat, and this activates certain defensive mechanisms that work to reduce its negative psychological impact (MacDonald and Leary, 2005). Research shows that people experiencing feelings of exclusion exhibit several behavioral characteristics, including: aggressive behavior (Kirkpatrick, Waugh, Valencia, and Webster, 2002); social avoidance (Watson and Nesdale, 2012); strategic spending to promote affiliation (Mead, Baumeister, Stillman, Rawn, and Vohs, 2011); positive attitudes towards ads and products that promote acceptance 
(Aghakhani and Main, 2018); choosing products with the goal of distinguishing themselves from other people (Wan, Xu, and Ding, 2014); risky behavior (Buelow and Wirth, 2017); and impaired logical reasoning (Baumeister et al., 2005).

To understand reactions to social exclusion, researchers have employed the concept of immune neglect, which describes people's failure to recognize different options for reducing future distress (Hoerger, 2012). In particular, when people encounter a negative event, they usually overestimate its long-lasting impact because they are unaware that they possess an unconscious coping system that helps to lessen the event's impact (Gilbert, Pinel, Wilson, Blumberg, and Wheatley, 1998). Psychological immune neglect uses various tactics to relieve negative feelings from negative events including bias towards positive information. For instance, it has been shown that people remember more positive memories from childhood following social exclusion than non-excluded people do (DeWall, Twenge, Koole, Baumeister, Marquez, and Reid, 2011). Therefore, people focus on positive cues in order to regulate the negative feelings that follow from social exclusion, while positive emotions become more accessible and desirable (Quirin, Bode, and Kuhl, 2011). It has been demonstrated that socially excluded people categorize words based on common positive emotions, not on negative ones, and that they give more weight to positive emotions in their judgement (Aghakhani and Main, 2019; DeWall et al., 2011).

Exclusion from social relations can potentially be a powerful blow, and emotional distress and cognitive turmoil from social exclusion can lead to self-destructive behavior. Many studies have also shown that socially excluded individuals have increased aggression, decreased intellectual capacity, decreased prosocial behavior, and self- defeat behavior patterns. In other words, social exclusion will cause people to feel anxiety and other forms of emotional pain and eventually to make self-destructive choices.

The most common form of self-defeating behavior is the pursuit of short-term benefits involving long-term costs such as smoking or even delaying satisfaction (Baumeister and Scher, 1988). This type of behavior is the use of counterproductive strategies. For example, some people try self-medication for depression by drinking, but find that drinking makes them more depressed. Choosing an unproductive strategy that takes short-term benefits with longterm or high costs often reflects that self-regulation is not fully undertaken. Behaviors such as substance abuse, minor pregnancy, and cheating are also self-destructive behaviors that result from poor self-regulation (Baumeister, Heatherton, and Tice, 1994). Other self-defeating behaviors, such as taking stupid risks and making unhealthy choices, end up showing a self-destructive tendency (Twenge, Catanese, Baumeister, 2002). It can be predicted that those who are not socially accepted will be involved in more self-defeating behavior.

The Escape Model (Heatherton and Baumeister, 1991) is built on concepts drawn from theories of selfawareness and comparisons with one's ideal self, and has been applied to a number of self-defeating behaviours, including binge eating (Baumeister and Scher, 1988; Heatherton and Baumeister, 1991), sexual masochism (Baumeister, 1990), suicide (Heatherton and Baumeister, 1991), and impulsive buying (Han, 2020b, 2020c). Although not an inherently aversive state, self-awareness can be burdensome, particularly when an individual has high, demanding, even perfectionist, standards and becomes aware that they are failing to meet their personal goals and ideals (Duval and Wicklund, 1972). If these discrepancies are internally attributed, people may experience negative emotion and individuals are motivated to escape this negative emotion. The escape model provides a framework for viewing how individuals might escape the aversive negative affective state (Blackburn, Johnston, Blampied, Popp, and Kallen, 2006). This escape from negative emotion increases the self-defeating behaviors, including binge eating. Escape from negative feelings through cognitive narrowing weaken usual inhibitions of food and facilitates further escape through narrowing attention. With additional cognitive narrowing prior inhibitions around eating are eroded, and eating escalates into a full-blown binge episode (Blackburn et al., 2006). Research proposes that compulsive purchasers share a propensity to fantasize, higher sorrow rates, materialistic directions, and more significant levels of uneasiness and fixation contrasted with different buyers (Faber and O'Guinn, 1992; Müller, Mitchell, Peterson, Faber, Steffen, Crosby, and Claes, 2011). Subsequently, issue goals aren't a deciding element in the appraisal of whether a specific conduct can be viewed as an adapting procedure since customers may assess the result of a circumstance as acceptable insofar as saw pressure was figured out how to the best of his/her capacity.

\subsection{Hypothesis Setting}

Compulsive buyers show compulsive behaviors as a way to cope with their stress, or to overcome negative situations (Faber, O'Guinn, and Krych, 1987). Negative emotions and events evoke compulsive buying and compulsive behaviors. Research suggests that consumers often resort to compulsive buying out of their need for affection and sense of belonging (O'Guinn and Faber, 1989). Ironically, such addictions often lead to isolation and estrangement from family and friends. 
Compulsive buyers employ cognitive narrowing by focusing their attention solely on the buying task, thus temporarily blocking out their anxieties. Due to their narrow attention during a buying episode, compulsive buyers fail to consider the long-term, negative consequences of their actions. Instead, they experience short-term improvements in mood which reinforces their behaviors and drives recurring acts of compulsion (O'Guinn and Faber, 1989).

Compulsive buyers temporarily avoid negative emotions through escapism and can get a relief by distancing themselves from stressful reality. When consumers "escape" stressful situations to avoid anxiety, they lose reality and are more susceptible to compulsive buying. In addition, consumers can experience more positive mood because compulsive buying allow them to move away from their anxieties. Meta-analytic evidence suggests that positive mood is positively related to compulsive consumption in adults (Cardi, Leppanen, and Treasure, 2015).

Based on the theoretical review so far, a similar process can be expected to work in compulsive buying and social exclusion experience. From the same principles as in the relationship between social exclusion and impulsive buying (Han, 2020b, 2020c), when consumers have high levels of negative emotions due to social exclusion, cognitive narrowing may occur to cope. As a result, cognitive distortion and failure of self-regulation can lead to compulsive buying in terms of consumption. In other words, a group that experienced social exclusion is more likely to buy obsessively than a group that has not experienced it. Therefore, the following hypothesis can be drawn.

Hypothesis: Groups who experienced social exclusion will show a higher tendency toward compulsive buying than those who have not experienced social exclusion.

\section{Methods and Results}

\subsection{Methods}

This study was conducted with 114 university students taking business administration classes in Seoul. Among the participants, 46 were female and 68 were male. Most of the participants were between the ages of 20 and 25 . We randomly assigned participants to the group who accomplished social exclusion or to the group who did not. We analyzed how the tendency of compulsive buying varies depending on the experience of social exclusion.

The study was conducted in the following order. The manipulation of social exclusion encounters has used situation manipulation methods for applying for enrollment (Wan, Xu, and Ding, 2014). Subjects were given a scenario and required to read it carefully. And subjects were emphasized the significance of taking the role of character and feelings while perusing the story as though in a similar occasion, all things considered. The scenario showed that the primary character preparing for employment seeks to join a job preparation club 'SUCCESS', that provides useful information and effective learning methods and has been proud of high employment success rates. The scenario includes that the primary character has submitted an enrollment application to the job preparation club. Under social exclusion situation, the character was touched by the club a few days later and was told that his or her application was rejected. And under social inclusion situation, the primary character was informed that his application was approved.

Next, participants answered to manipulation check question (i.e., feelings of exclusion or neglect) on Likert type 7 point scale $(1=$ strongly disagree, $7=$ strongly agree $)$. And then they responded to the questions about the tendency of compulsive buying. Compulsive buying tendency was measured using the Compulsive Buying Screen (CBS) adapted from Faber and O'Guinn (1992). 'If I have any money left at the end of the pay period, I just have to spend it,' 'I felt others would be horrified if they knew of my spending habits,' 'I bought things even though I couldn't afford them,' 'I used a credit card when I knew I didn't have enough money in the bank to cover it,' 'I bought myself something in order to make myself feel better,' 'I felt anxious or nervous on days I didn't go shopping,' 'I made only the minimum payments on my credit cards.'

It is a 7-point validated screening tool developed to measure compulsive buying behavior and Cronbach' $\alpha$ is reported to be .89 . The low score on this scale can be seen as a sign of a high compulsive buying tendency. 


\subsection{Results}

As shown in Table 1, responses to the manipulation check questionnaire were averaged (Wan et al., 2014), Participants under rejected condition (vs. accepted condition) showed more excluded feeling ( $M=4.78 \mathrm{vs.} \mathrm{M}=3.07, \mathrm{t}$ $(112)=8.878, \mathrm{p}<.001)$, proving the manipulation success of social exclusion.

Table 1: The Manipulation check of Social Exclusion

\begin{tabular}{|c|c|c|c|c|c|}
\hline & & N & Mean & SD & Standard Error of the Mean \\
\hline $\begin{array}{c}\text { Feelings of } \\
\text { Exclusion }\end{array}$ & Social Exclusion & 59 & 4.78 & 1.035 & .135 \\
\cline { 2 - 6 } & Social Inclusion & 55 & 3.07 & 1.016 & .137 \\
\hline
\end{tabular}

\begin{tabular}{|c|c|c|c|c|c|c|c|c|c|c|}
\hline & \multirow{2}{*}{\multicolumn{2}{|c|}{$\begin{array}{l}\text { Levene's Test } \\
\text { for Equality of } \\
\text { Variances }\end{array}$}} & & \multicolumn{6}{|c|}{ t-test for Equality of Means } \\
\hline & & & & \multirow[t]{2}{*}{$\mathbf{t}$} & \multirow[t]{2}{*}{ df } & \multirow[t]{2}{*}{$\begin{array}{l}\text { Sig. (2- } \\
\text { tailed) }\end{array}$} & \multirow[t]{2}{*}{$\begin{array}{c}\text { Mean } \\
\text { Difference }\end{array}$} & \multirow[t]{2}{*}{$\begin{array}{l}\text { Std. Error } \\
\text { Difference }\end{array}$} & \multicolumn{2}{|c|}{$\begin{array}{c}95 \% \\
\text { Confidence } \\
\text { Interval of the } \\
\text { Difference }\end{array}$} \\
\hline & & $\mathbf{F}$ & Sig. & & & & & & Lower & $\begin{array}{c}\text { Upp } \\
\text { er }\end{array}$ \\
\hline \multirow{2}{*}{$\begin{array}{l}\text { Feelings } \\
\text { of } \\
\text { Exclusion }\end{array}$} & $\begin{array}{c}\text { Equal } \\
\text { variance } \\
\text { assumed }\end{array}$ & .075 & .785 & 8.878 & 112 & .000 & 1.707 & .192 & 1.326 & 2.088 \\
\hline & $\begin{array}{c}\text { Equal } \\
\text { variance } \\
\text { not } \\
\text { assumed }\end{array}$ & & & 8.884 & 111.698 & .000 & 1.707 & .192 & 1.326 & 2.088 \\
\hline
\end{tabular}

As shown in Table 2 and Figure 1, social exclusion experience group showed the higher compulsive buying tendency than that of the social exclusion non-experience group $\left(\mathrm{M}_{e x}=2.82\right.$ vs. $\left.\mathrm{M}_{i n}=3.12, \mathrm{t}(112)=-3.632, \mathrm{p}<.001\right)$. These results support the hypothesis that the social exclusion experience increases compulsive buying tendency.

Table 2: The Effect of Social Exclusion on Compulsive Buying Tendency

\begin{tabular}{|c|c|c|c|c|c|}
\hline & & N & Mean & SD & Standard Error of the Mean \\
\hline $\begin{array}{c}\text { Compulsive } \\
\text { Buying } \\
\text { Tendency }\end{array}$ & Social Exclusion & 59 & 2.8184 & .47219 & 1.648 \\
\cline { 2 - 6 } & Social Inclusion & 55 & 3.1195 & .40757 & 1.492 \\
\hline
\end{tabular}

\begin{tabular}{|c|c|c|c|c|c|c|c|c|c|c|}
\hline & \multirow{2}{*}{\multicolumn{2}{|c|}{$\begin{array}{l}\text { Levene's } \\
\text { Test for } \\
\text { Equality of } \\
\text { Variances } \\
\end{array}$}} & \multicolumn{7}{|c|}{ t-test for Equality of Means } \\
\hline & & & & \multirow[t]{2}{*}{$\mathbf{t}$} & \multirow[t]{2}{*}{ df } & \multirow{2}{*}{$\begin{array}{l}\text { Sig. (2- } \\
\text { tailed) }\end{array}$} & \multirow{2}{*}{$\begin{array}{c}\text { Mean } \\
\text { Difference }\end{array}$} & \multirow{2}{*}{$\begin{array}{l}\text { Std. Error } \\
\text { Difference }\end{array}$} & \multicolumn{2}{|c|}{$\begin{array}{l}\mathbf{9 5 \%} \text { Confidence } \\
\text { Interval of the } \\
\text { Difference }\end{array}$} \\
\hline & & $\mathbf{F}$ & Sig. & & & & & & Lower & Upper \\
\hline \multirow{2}{*}{$\begin{array}{c}\text { Compulsive } \\
\text { Buying } \\
\text { Tendency }\end{array}$} & $\begin{array}{c}\text { Equal } \\
\text { variance } \\
\text { assumed }\end{array}$ & 1.378 & .243 & -3.632 & 112 & .000 & -.30108 & .08289 & -.46530 & -.13685 \\
\hline & $\begin{array}{c}\text { Equal } \\
\text { variance } \\
\text { not } \\
\text { assumed }\end{array}$ & & & -3.651 & 11.358 & .000 & -.30108 & .08246 & -.46447 & -.13769 \\
\hline
\end{tabular}




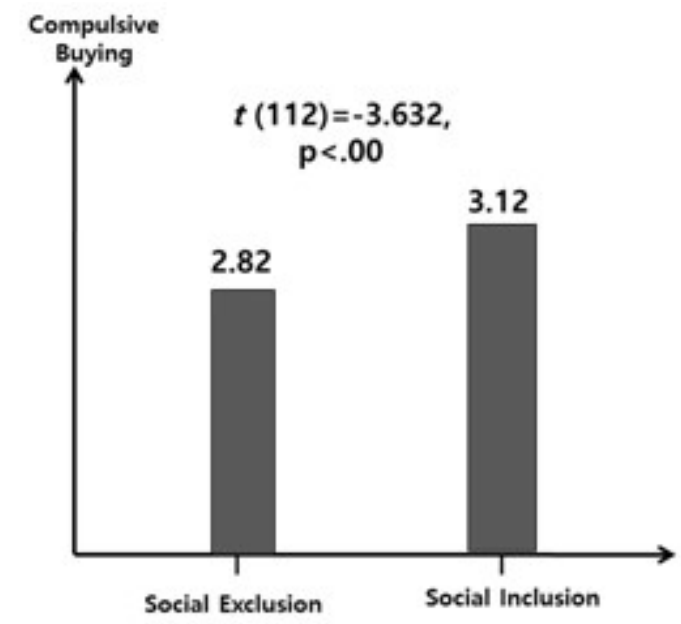

Figure 1: Social Exclusion and Compulsive Buying

\section{Conclusion}

This study found that the compulsive buying tendency varies depending on whether or not social exclusion has been experienced. This result indicates that when the social exclusion experience causes negative emotion, this negative emotion narrows cognition focusing on specific, immediate, and low-level tasks including shopping, which leads to self-defeating behavior. This also supports the prediction that self-regulation or self-control of purchasing behavior tends to fail.

This study investigated the compulsive buying which is a sort of deviant consumption. Current research highlighted the role of social exclusion experience, cognitive narrowing, negative emotions and self-regulation in the compulsive buying. Specifically, in order to overcome negative emotions from social exclusion, the degree of cognition and judgment is maintained at a low and narrow level. And this state will lead to the lower levels of attention and regulation. Consequently, this cognitive narrowing will increase the compulsive buying.

Exclusion from social relations can potentially be an emotional distress and cognitive turmoil from social exclusion can lead to self-destructive behavior. Many studies have also shown that socially excluded individuals have increased aggression, decreased intellectual capacity, decreased prosocial behavior, and self- defeat behavior patterns. In other words, social exclusion will cause people to feel anxiety and other forms of emotional pain and eventually to make self-destructive choices.

According to Faber et al. (1987), consumers engage in compulsive buying so as to cope with stress or to overcome negative emotions. Also, compulsive buyers employ cognitive narrowing by focusing their attention solely on the buying task, thus temporarily blocking out their anxieties and due to their narrow attention during a buying episode and compulsive buyers fail to consider the long-term, negative consequences of their actions (Darrat, Darrat, and Amyx, 2016). O'Guinn and Faber (1989) suggested a lack of sense of belonging as a negative emotion that people want to escape through compulsive buying but didn't elaborate on the relationship between the two. This study investigated the effect of lack of sense of belonging from social exclusion experience on compulsive buying and revealed that there was a significant relationship between the two. Therefore, this study contributes theoretically by showing the psychological mechanism compulsive buying and social exclusion. And this study has theoretical significance in that it confirmed that the relationship of self-destructive behavior due to social exclusion can be applied not only to impulsive buying (Han, 2020b, 2020c), but also to compulsive buying.

In practice, it is necessary to be cautious about approaching obsessive purchases only from a marketing strategic point of view, for compulsive consumption can be defined as "a response to an uncontrollable drive or desire to obtain, use, or experience a feeling, substance, or activity that leads an individual to repetitively engage in a behavior that will ultimately cause harm to the individual and/or to others" (O'Guinn and Faber, 1989). In this regard, it may be more important to identify the psychological factors in which compulsive buying occur and to devise measures to prevent compulsive purchases. In other words, a society-wide effort to minimize negative emotions arising from the social alienation of consumers will be required and it is also necessary to develop and educate ways to manage and overcome various negative emotions experienced in everyday life. Therefore, it is 
necessary to ensure that negative consumption, such as compulsive buying, is not prevalent. Marketing strategic implications for compulsive buying can be found clearly in online shopping. Considering that the study that compulsive buyers spend four times more time on the Internet than noncompulsive buyers (Lejoyeux et al., 2007) and that social exclusion investigated in this study can occur more frequently online than offline, marketing efforts that emphasize the sense of belonging in the online environment or virtual space and stimulate fear of alienation can be expected to be effective. And it is required for marketing managers to carefully identify consumer types sensitive to social exclusion and emphasize the value of products, while considering consumers' emotion.

This study has some limitations that the example was collected from university students, not various consumers, and did not compare social exclusion with other measurement tools of cognitive narrowness. Also, this research investigated only the effects of social exclusion on compulsive buying, however future studies need to investigate various kinds of self-defeating behaviors. In addition, it is necessary to study consumer behaviors such as abandonment of consumption in relation to social exclusion.

\section{Reference}

Achtziger, A., Hubert, M., Kenning, P., Raab, G., \& Reisch, L. (2015). Debt out of control: The links between selfcontrol, compulsive buying, and real debts. Journal of Economic Psychology, 49(August), 141-149.

Aghakhani, H., \& Main, K.J. (2018). The impact of social exclusion and permeability on consumers' responses towards advertising. In: Cauberghe, V., Hudders, L., Eisend, M. (Eds.), Advances in Advertising Research $I X$. Springer-Gabler, 317-327.

Aghakhani, H., \& Main, K.J. (2019). Can two negatives make a positive? Social exclusion prevents carryover effects from deceptive advertising? Journal of Retailing and Consumer Services, 47(3), 206-214.

Balabanis, G. (2002). The relationship between lottery ticket and scratch-card buying behavior, personality and other compulsive behaviours. Journal of Consumer Behavior, 2(1), 7-22.

Baumeister, R. F. (1990). Anxiety and deconstruction: On escaping the self. In J. M. Olson and M. P. Zanna (Eds.), Self-inference processes: The Ontario symposium, 6, 259-291.

Baumeister, R.F., DeWall, C.N., Ciarocco, N.J., \& Twenge, J.M. (2005). Social exclusion impairs self-regulation. Journal of Personality and Social Psychology, 88(4), 589-604.

Baumeister, R. F., Heatherton, T. F., \& Tice, D. M. (1994). Losing control: How and why people fail at selfregulation. San Diego, CA: Academic Press.

Baumeister, R. F., \& Scher, S. J. (1988). Self-defeating behavior patterns among normal individuals: Review and analysis of common self-destructive tendencies. Psychological Bulletin, 104(1), 3-22.

Baumeister, R. F., Vohs, K. D., DeWall, N., \& Zhang, L. (2007). How emotion shapes behavior: Feedback, anticipation, and reflection, rather than direct causation. Personality and Social Psychology Review, 11(2), 167-203.

Billieux, J., Rochat, L., My Lien Rebetez, M., \& Van der Linden, M. (2008). Are all facets of impulsivity related to self-reported compulsive buying behaviour? Personality and Individual Differences, 44(6), 1432-1442.

Black, D. W. (2007). A review of compulsive buying disorder. World Psychiatry, 6(1), 14-18.

Blakcburn, S., Johnston, L., Blampied, N., Popp, D., \& Kallen, R. (2006). An application of escape theory of binge eating. European Eating Disorder Review, 14(1), 23-31.

Buelow, M.T., \& Wirth, J.H. (2017). Decisions in the face of known risks: ostracism increases risky decisionmaking. Journal of Experimental Social Psychology, 69(3), 210-217.

Cardi, V., Leppanen, J., \& Treasure, J. (2015). The effects of negative and positive mood on eating behavior: A meta-analysis of laboratory studies in the healthy population and eating and weight disorders. Neuroscience and Biobehavioral Reviews, 579(October), 299-309.

Cherrier, H., \& Ponnor, T. (2010). A study of hoarding behavior and attachment to material possessions. Qualitative Market Research, 13(1), 8-23.

Christenson, G., Faber, R. J., DeZwaan, M., Raymond, N. C., Specker, S. M., \& Ekern, M. D. (1994). Compulsive buying: Descriptive characteristics and psychiatric comorbidity. Journal of Clinical Psychiatry, 55(1), 511. 
Darrat, A. A., Darrat, M. A., and Amyx, D. (2016). How impulse buying influences compulsive buying: The central role of consumer anxiety and escapism, Journal of Retailing and Consumer Services, 31(July), 103-108.

DeWall, C.N., Twenge, J.M., Koole, S.L., Baumeister, R.G., Marquez, A., \& Reid, M.W. (2011). Automatic emotion regulation after social exclusion: tuning to positivity. Emotion 11(3), 623-636.

Dittmar, H. (2005). A new look at "compulsive buying": Self-discrepancies and materialistic values as predictors of compulsive buying tendency. Journal of Social and Clinical Psychology, 24(6), 832.

Dittmar, H., Long, K., \& Bond, R. (2007). When a better self is only a button click away: Associations between materialistic values, emotional and identity-related buying motives, and compulsive buying tendency online. Journal of Social and Clinical Psychology, 26(3), 334-361.

Duroy, D., Gorse, P., \& Lejoyeux, M. (2014). Characteristics of online compulsive buying in Parisian students. Addictive behaviors, 39(12), 1827-1830.

Duval, S., \& Wicklund, R. A. (1972), A theory of objective self-awareness. San Diego, CA: Academic Press.

Faber, R. J. (2000). A systematic investigation into compulsive buying. In A. L. Benson (Eds.), I shop, therefore I am: Compulsive buying and the search for self (pp.27-54). Northvale, NJ: Aronson Press.

Faber, R. J. (2004). Self-control and compulsive buying. In T. Kasser and A. D. Kanner (Eds.), Psychology and consumer culture: The struggle for a good life in a materialistic world (pp. 169-187). Washington: The American Psychological Association.

Faber, R. J., \& Christenson, G. A. (1996). In the mood to buy: Differences in the mood states experienced by compulsive buyers and other consumers. Psychology and Marketing, 13(8), 803-820.

Faber, R. J., Christenson, G. A., De Zwaan, M., \& Mitchell, J. (1995). Two forms of compulsive consumption: Comorbidity of compulsive buying and binge eating. Journal of Consumer Research, 22(3), 296-304.

Faber, R. J., \& O'Guinn, T. C. (1988). Compulsive consumption and credit abuse. Journal of Consumer Policy, 11(1), 97-109.

Faber, R. J., \& O'Guinn, T. C. (1989). Classifying compulsive consumers: Advances in the development of a diagnostic tool. In T. K. Srull (Eds.), Advances in consumer research (Vol. 16) (pp. 738-744). Provo, UT: Association for Consumer Research.

Faber, R. J., \& O'Guinn, T. C. (1992). A clinical screener for compulsive buying. Journal of Consumer Research, 19(3), 459-469.

Faber, R. J., O’Guinn, T. C., \& Krych, R. (1987). Compulsive consumption. Advances in Consumer Research, 14(1), 132-135.

Gallagher, C. E., Watt, M. C., Weaver, A. D., \& Murphy, K. A. (2017). “I fear, therefore, I shop!" exploring anxiety sensitivity in relation to compulsive buying. Personality and Individual Differences, 104(January), 37-42.

Gilbert, D.T., Pinel, E.C., Wilson, T. D., Blumberg, S.J., \& Wheatley, T.P. (1998). Immune neglect: a source of durability bias in affective forecasting. Journal of Personality and Social Psychology, 75(3), 617-639.

Han, W. H. (2020a). Does social exclusion influence consumers' pseudodiagnosticity biases towards distribution brands? Journal of Distribution Science, 18(4), 79-85.

Han, W. H. (2020b). Impulsive buying and social exclusion. Journal of Product Research, forthcoming.

Han, W. H. (2020c). How consumers' mindfulness moderates impulsive buying tendency. Services Marketing Journal, forthcoming.

Heatherton, T. F., \& Baumeister, R. F. (1991). Binge eating as escape from self-awareness. Psychological Bulletin, 110(1), 86-108.

Hirschman, E. C. (1991). Secular mortality and the dark side of consumer behavior: Or how semiotics saved my life. In Solomon, M. R., \& Holman, R. (Eds.) Advances in consumer research. Provo, UT: Association for Consumer Research. 18(1), 1-4.

Hoerger, M. (2012). Coping strategies and immune neglect in affective foresting: direct evidence and key moderators. Judgment and Decision Making, 7(1), 86-89.

Johnson, T., \& Attmann, J. (2009). Compulsive buying in a product specific context: Clothing. Journal of Fashion Marketing Management, 13(3), 394-405.

Johnson, C., Connors, M. E., \& Tobin, D. L. (1987). Symptom management of bulimia, Journal of Consulting and Clinical Psychology, 55(5), 668-676.

Kacen, J. J., \& Lee, J. A. (2002). The influence of culture on consumer impulsive buying behavior. Journal of Consumer Psychology, 12(2), 163-176.

Kirkpatrick, L.A., Waugh, C.E., Valencia, A., \& Webster, G.D. (2002). The functional domain specificity of selfesteem and the differential prediction of aggression. Journal of Personality and Social Psychology, 82(5), $756-767$. 
Koran, L. M., Faber, R. J., Aboujaoude, E., Large, M. D., \& Serpe, R. T. (2006). Estimated prevalence of compulsive buying behavior in the United States. American Journal of Psychiatry, 163(10), 1806-1812.

Krueger, D. (2000). The Use of money as an action symptom. In A. L. Benson (Eds.), I shop, therefore, I am: Compulsive buying and the search for self (pp.288-310). Northvale, NJ: Aronson Press.

Kukar-Kinney, M., Ridgway, N. M., \& Monroe, K. B. (2009). The relationship between consumers' tendencies to buy compulsively and their motivation to shop and buy on the Internet. Journal of Retailing, 85(3), 298307.

Kukar-Kinney, M., Ridgway, N. M., \& Monroe, K. B. (2012). The role of price in the behavior and purchase decisions of compulsive buyers. Journal of Retailing, 88(1), 63-71.

Kukar-Kinney, M., Scheinbaum, A. C., \& Schaefers, T. (2016). Compulsive buying in online daily deal settings: An investigation of motivations and contextual elements. Journal of Business Research, 69(2), 691-699.

Lazarus, R. S., \& Folkman, S. (1984). Stress, appraisal, and coping. Springer Publishing, New York, NY.

Lejoyeux, M., Mathieu, K., Embouazza, H., Huet, F., \& Lequen, V. (2007). Prevalence of compulsive buying among customers of a Parisian general store. Comprehensive Psychiatry, 48(1), 42-46.

MacDonald, G., \& Leary, M. R. (2005), Why does social exclusion hurt? The relationship between social and physical pain. Psychological Bulletin, 131(2), 202-223.

McElroy, S. L., Keck, P. E., Jr., \& Phillips, K. A. (1995). Kleptomania, compulsive buying and binge eating disorder. Journal of Clinical Psychiatry, 56(4), 14-26.

Mead, N. L., Baumeister, R. F., Stillman, T. F., Rawn, C. D., \& Vohs, K. D. (2011). Social exclusion causes people to spend and consume strategically in the service of affiliation. Journal of Consumer Research, 37(5), 902-919.

Miltenberger, R. G., Redlin, J., Crosby, R., Stickney, M., Mitchell, J., Wonderlich, S., ... Smyth, J. (2003). Direct and retrospective assessment of factors contributing to compulsive buying. Journal of Behavior Therapy and Experimental Psychiatry, 34(1), 1-9.

Müller, A., Mitchell, J. E., Peterson, L. A., Faber, R. J., Steffen, K. J., Crosby, R. D., \& Claes, L. (2011). Depression, materialism, and excessive internet use in relation to compulsive buying. Comprehensive Psychiatry, 52(4), 420-424.

O'Guinn, T. C., \& Faber, R. J. (1989). Compulsive buying: A phenomenological exploration. Journal of Consumer Research, 16(2), 147-157.

Palan, K. M., Morrow, P. C., Trapp, A., \& Blackburn, V. (2011). Compulsive buying behavior in college students: The mediating role of credit card misuse. Journal of Marketing Theory and Practice, 19(1), 81-96.

Quirin, M., Bode, R.C., \& Kuhl, J. (2011). Recovering from negative events by boosting implicit positive affect. Cognition and Emotion, 25(3), 559-570.

Raab, G., Elger, C. E., Neuner, M., \& Weber, B. (2011). A neurological study of compulsive buying behavior. Journal of Consumer Policy, 34(4), 401-413.

Rawn, C. D., \& Vohs, K. D. (2010). When people strive for self-harming goals: Sacrificing personal health for interpersonal success. In R. F. Baumeister \& K. D. Vohs (Eds.), Handbook of self-regulation: Research, theory, and applications (pp.374-389), New York, NY: The Guilford Press.

Ridgway, N. M., Kukar-Kinney, M., \& Monroe, K. B. (2008). An expanded conceptualization and a new measure of compulsive buying. Journal of Consumer Research, 35(4), 622-639.

Roberts, J. A. (1998). Compulsive buying among college students: An investigation of its antecedents, consequences, and implications for public policy. Journal of Consumer Affairs, 32(2), 295-319.

Schlosser, S., Black, D. W., Repertinger, S., \& Freet, D. (1994). Compulsive buying: Demography, phenomenology, and comorbidity in 46 subjects. General Hospital Psychiatry, 16(3), 205-212.

Twenge, J. M., Catanese, K. R., \& Baumeister, R. F. (2002). Social exclusion causes self-defeating behavior. Journal of Personality and Social Psychology, 83(3), 606-615.

Valenc, G., d'Astous, A., \& Fortier, L. (1988). Compulsive buying: concept and measurement. Journal of Consumer Policy, 11(4), 419-433.

Wan, E. C., Xu, J., \& Ding, Y. (2014). To be or not to be unique? The effect of social exclusion on consumer choice. Journal of Consumer Research, 40(6), 1109-1122.

Watson, J., \& Nesdale, D. (2012). Rejection sensitivity, social withdrawal, and loneliness in young adults. Journal of Applied Social Psychology, 42(8), 1984-2005.

Weinstein, A., Maraz, A., Griffiths, M. D., Lejoyeux, M., \& Demetrovics, Z. (2016). Compulsive buying - features and characteristics of addiction. In V. Preedy (Vol. Ed.), The neuropathology of drug addictions and substance misuse: Vol. 3, (pp.993-1008). London: Academic Press. 
Weinstein, A., Mezig, H., Mizrachi, S., \& Lejoyeux, M. (2015). A study investigating the association between compulsive buying with measures of anxiety and obsessive-compulsive behavior among internet shoppers. Journal of Comprehensive Psychiatry, 57(February), 46-50.

Yi, S. (2012). Shame-proneness as a risk factor of compulsive buying. Journal of Consumer Policy, 35(3), 393-410. 